\title{
A Potential for the Use of Dragonfly (Odonata) Diversity as a Bioindicator of the Efficiency of Sewage Lagoons
}

\author{
PAUl M. CATLING
}

Biology, University of Ottawa, 30 Marie Curie, Ottawa, Ontario K1N 6N5 Canada; catlingp@em.agr.ca

Catling, Paul M. 2005. A potential for the use of dragonfly (Odonata) diversity as a bioindicator of the efficiency of sewage lagoons. Canadian Field-Naturalist 119(2): 233-236.

In order to determine whether a relationship existed between water quality and odonate fauna in sewage ponds, data were gathered at each of six ponds of similar construction and equal size and depth in an adjacent series of improving water quality at a lagoon system near Embrun in eastern Ontario. Numbers of nymphs of different species of Odonata were recorded in spring and fall, and similar data was collected on adults in June and July. The data on species presence and abundance for each of three pairs of cells in the sequence was then compared with the corresponding chemical data which included biological oxygen demand, total phophorus, total nitrogen and suspended solids. Water quality improved through the system and species diversity in the final ponds was twice that of the ponds receiving wastewater. Numbers of individuals also increased through the system. Occurrence of Anax junius, Enallagma civile and Ischnura verticalis alone was associated with poorer water quality. Higher diversity including Lestes disjunctus, Leucorrhinia spp. and Erythemis simplicicollis, indicates higher water quality. A potential exists for Odonata species diversity, numbers of individuals and occurrence of particular species to be used as a bioindicator of water quality and a means of evaluating efficiency of a lagoon system. Advantages include data that reflects a time period rather than a point in time and also low costs.

Key Words: Odonata, dragonflies, bioindicator, biodiversity, sewage lagoons, pollution, water quality, Ontario, Canada.

Sewage lagoons, a cost-effective form of waste treatment, are widespread in Canada, especially in sparsely populated regions. Many of the present lagoon systems in eastern Canada were developed after 1950 (Manoharan 1985). They soon became recognized as a distinctive environment resembling western prairie sloughs in their high productivity and biological composition. Lagoon systems are characterized by a series of pools of increasing water quality from the first receiving water with raw sewage to the last receiving water that has had substantial treatment. This sequence provides an opportunity for assessing association of aquatic species and abundance in relation to water quality. Such information can be applied to an assessment of the efficiency of a lagoon system.

Biodiversity and numbers of individuals of dragonflies have been shown to be related to water quality worldwide (e.g., Watson et al. 1982; Takamura 1991; Corbet 1999) and in Canada (Lefort and Catling 1998), but their potential use in evaluating sewage lagoon systems has not been studied. A preliminary investigation (Catling 2004) suggested a relationship between water quality and dragonfly species presence and abundance in sewage lagoons and identified species groups representative of good and poor water quality. Although useful, this study was based indirectly on water quality through a demonstrated correlation with water clarity. The present work adds to this by elucidating the direct relationship with specific values of water quality parameters in a series of sewage ponds. The objective was to further explore the extent to which dragonflies have a potential use in evaluating the efficiency of sewage lagoon systems.

\section{Methods}

Each of six ponds of similar construction and equal size and depth in an adjacent series of improving water quality were sampled at a lagoon system near Embrun $\left(45.2767^{\circ} \mathrm{N}, 75.2359^{\circ} \mathrm{W}\right)$ in eastern Ontario. Numbers of nymphs of different species of Odonata were recorded in spring and fall (15 October 2001 and 17 April 2002), and similar data were collected on adults in summer (26 June 2002 and 18 July 2002). The data on species presence and abundance for each of three pairs of cells in the sequence were then compared with the corresponding chemical data which included biological oxygen demand (BOD), total phophorus (TP), total nitrogen (TN) and suspended solids (SS). The data included three measurements (fall 2001, spring 2002, fall 2002) of each parameter from each of the six sewage ponds. All measurements $(\mathrm{mg} / \mathrm{L})$ were made at Accutest Laboratories in Ottawa on behalf of the township of Russell. These measurements were averaged to provide an indication of overall conditions. Since adjacent sewage ponds and even parts of ponds appear to vary greatly in water chemistry due to the time of year, amount of input and other factors relating to speed of breakdown, the point samples can only be considered to indicate a trend in the sequence. To compensate for variation, chemical data in each adjacent pair of cells (in the sequence of six) were averaged. This averaging also accounted for the bypassing of cells 1,3 and 5 during periods of heavy use, making certain sequential pairs of cells similar.

Nymphs were sampled with 50 scoops of a net at each of the six ponds on each of two visits. Thus it was the potential and successful overwintering nymph pop- 
TABLE 1. Number of nymphs of species of Odonata found in spring (S), fall (F) and the total (T) for three pairs of cells at the Embrum lagoon system.

\begin{tabular}{lrrrrrrrrr}
\hline \hline Species & & 1,2 & & & 3,4 & & & 5,6 & \\
& $\mathrm{~S}$ & $\mathrm{~F}$ & $\mathrm{~T}$ & $\mathrm{~S}$ & $\mathrm{~F}$ & $\mathrm{~T}$ & $\mathrm{~S}$ & $\mathrm{~F}$ & $\mathrm{~T}$ \\
\hline Anax junius & - & 2 & 2 & 197 & 80 & 277 & 10 & 35 & 45 \\
Enallagma civile & - & 50 & 50 & 24 & 210 & 234 & 100 & 265 & 365 \\
Enallagma cyathigerum & - & - & - & - & - & - & 60 & 37 & 97 \\
Erythemis simplicicollis & - & - & - & - & - & - & 1 & - & 1 \\
Ischnura verticalis & 10 & 150 & 160 & -34 & 135 & 169 & 20 & 160 & 180 \\
Lestes disjunctus & - & - & - & - & - & - & - & 8 & 8 \\
Leucorrhinia proxima & - & - & - & - & - & - & 20 & - & 20 \\
Leucorrhinia intacta & - & - & - & - & - & - & 3 & - & 3 \\
Libellula quadrimaculata & - & 10 & 10 & - & - & - & 5 & 5 & 10 \\
Libellula pulchella & - & - & - & - & - & - & 7 & 3 \\
\hline \hline
\end{tabular}

TABLE 2. Total number of adults of species of Odonata recorded on two summer visits to the Embrun lagoons.

\begin{tabular}{lcrr}
\hline \hline Species & 1,2 & 3,4 & 5,6 \\
\hline Anax junius & 5 & 30 & 55 \\
Enallagma civile & 5 & 400 & 795 \\
Enallagma cyathigerum & - & 80 & 60 \\
Epitheca cynosura & - & 6 & 3 \\
Ischnura verticalis & 10 & 190 & 242 \\
Lestes disjunctus & - & - & 1 \\
Tramea lacerata & - & - & 1 \\
\hline \hline
\end{tabular}

ulations that were sampled. Sample points were approximately equally distributed around the edges of the lagoons. The nymphs were identified using the keys in Walker (1953). The heavily mottled body, long-pointed caudal lamellae and eyes with horizontal black lines, made the identification nymphs of Eastern Forktail (Ischnura verticalis) relatively simple. Nymphs of the species of bluets (Enallagma) were less easily identified. They were assigned to taxa in the field based on characteristics of the caudal lamellae evaluated with a $15 \times$ hand lens. In cases where the numbers of larvae exceeded a hundred, species composition was often based on microscopic examination of $20-50 \%$ of the total identified in the field. Approximately $95 \%$ of field identifications were correct. Adults were surveyed over a period of two hours on each of two dates with approximately 20 minutes spent at each of the six ponds.

\section{Results and Discussion}

At the Embrun lagoon system it is clear that biological oxygen demand, total nitrogen and suspended solids decrease from the lagoons receiving wastewater to the final "polishing ponds" that release treated effluent back to surface water drainage (Figure 1). Total Phosphorus is highest in the mid-portion of the system, possibly due to gradual release from organic matter and then precipitation in the middle part of the process. The water in the final pool of the Embrun system is relatively clean and well below the $25 \mathrm{mg} / \mathrm{L}$ compliance criteria for biological oxygen demand (BOD) and suspended solids (SS). Associated with this increase in water quality through the series of ponds, both the numbers of individuals and the numbers of species of dragonflies increases (Tables 1 and 2, Figure 2). Numbers of individuals of nymphs were not that much higher in the final ponds than in the middle ponds in the series (Figure 2 ), but there were large numbers of the few species present. The increase in diversity of species and numbers of individuals with improving water quality supports similar findings in studies comparing polluted and non-polluted waters (e.g., Watson et al. 1982; Takamura 1991; Lefort and Catling 1998; Corbet 1999).

Northern Spreadwing (Lestes disjunctus), whitefaces (Leucorrhinia spp.) and Eastern Pondhawk (Erythemis simplicicollis) were found only in the ponds with superior water quality as was the case in a preliminary study of several eastern Ontario lagoon systems based on correlates of water quality rather than actual values (Catling 2004). In addition the three species characteristic of the lowest water quality in that correlative study were same three found alone in the poor quality ponds at Embrun; i.e., Common Green Darner (Anax junius), Familiar Bluet (Enallagma civile) and Eastern Forktail (Ischnura verticalis). Data are insufficient to give an accurate indication of the tolerance limits of 

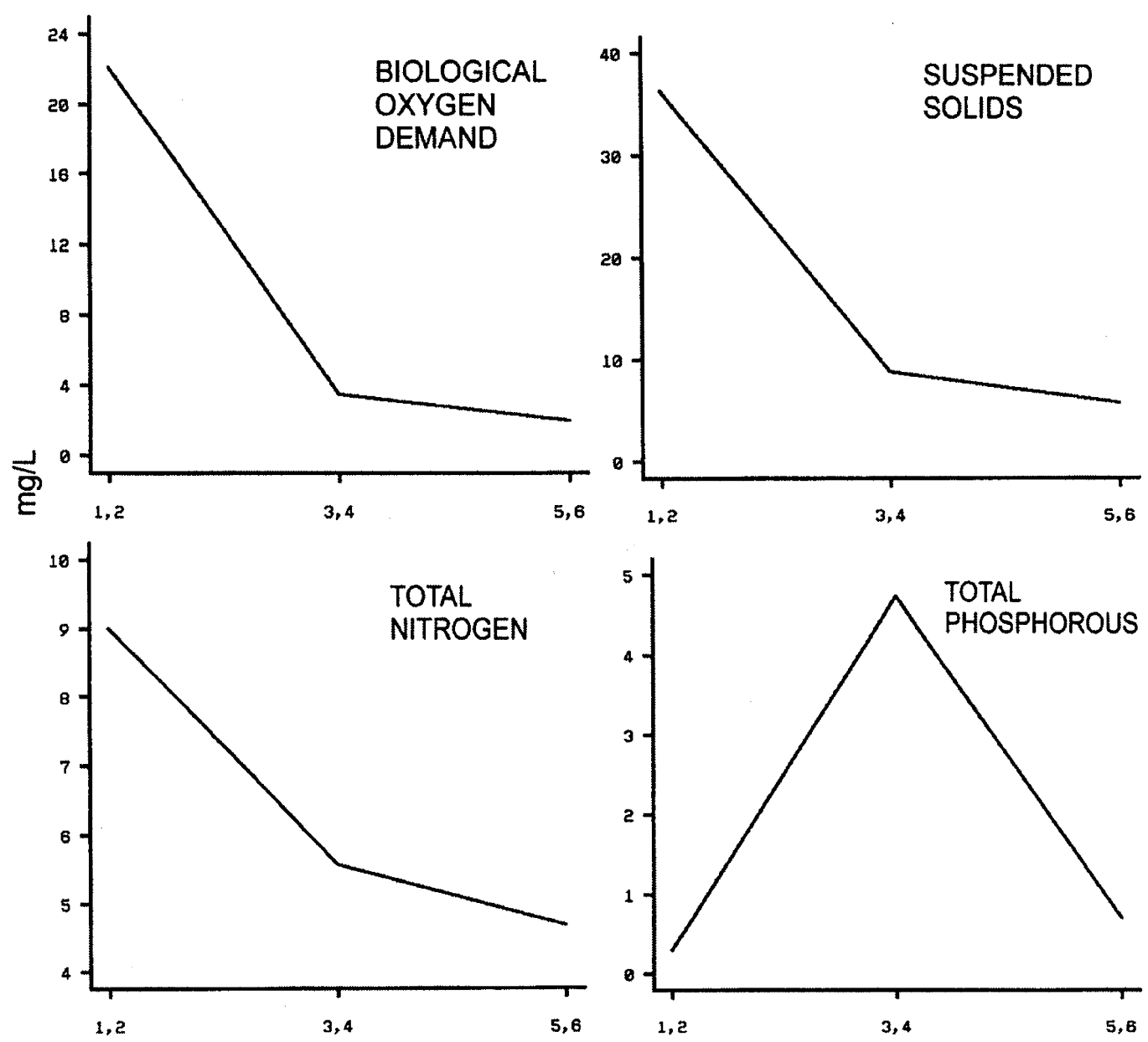

Treatment ponds (in sequence)

FIGURE 1. Mean measurements of chemical parameters at Embrun, eastern Ontario, based on sampling of the six ponds on three separate dates (22 October 2001, 26 February 2002, 15 October 2002).

different species, but average chemical conditions associated with dragonfly populations can be estimated from Figures 1 and 2 .

The first lagoons were poorer in species diversity and numbers in the spring than in the fall possibly due to decreased rate of decomposition and reduced oxygen during the winter months resulting in extreme conditions that eliminated much of the fauna in the initial ponds. Nymphs in early spring may provide the best indication of water quality due to direct association with water following a period of stress. However, adults appear to be able to recognize water quality and some species tend to occur only on the cleaner ponds (Figure 2). Overall the increase in species diversity in the final ponds is twice that of the ponds receiving wastewater.
This study suggests that the improving water quality in a series of sewage ponds is reflected by increasing odonate species diversity and increasing numbers of individuals of both aquatic larvae and aerial adults. The use of the indicator species is particularly promising and can be used in conjunction with diversity and numbers. The potential to use dragonflies as a bioindicator of the efficiency of sewage ponds requires additional study to confirm this suggestion over a broad area. It has two obvious advantages over chemical tests: (1) It includes reference to a time period (the larvae living in the pond for at least several weeks) rather than a single chemical sample at one particular point in time that may or may not be representative of conditions over the longer period. (2) It is inexpensive and can be done at most times of year using 

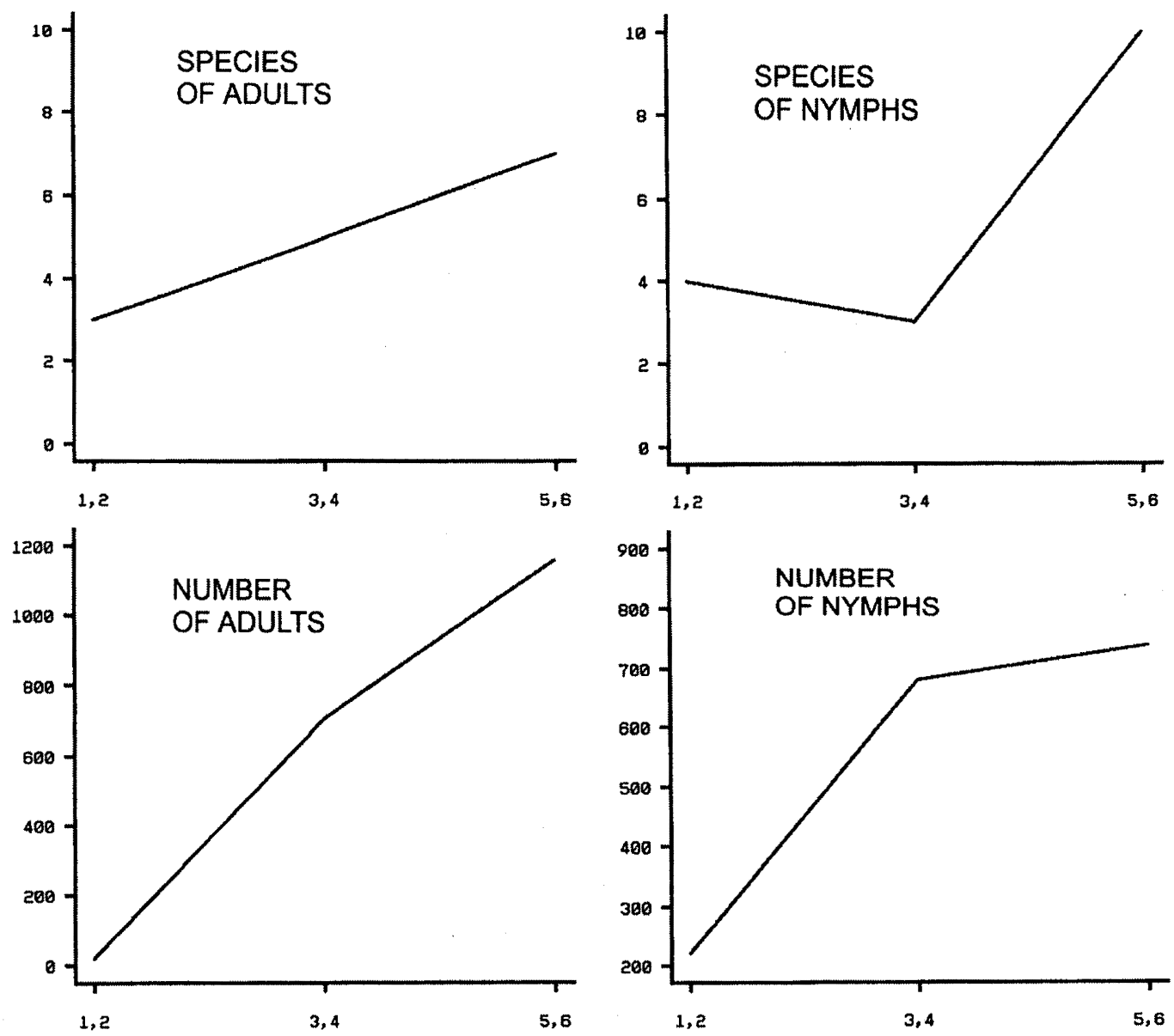

Treatment ponds (in sequence)

FIGURE 2. Numbers of species and individuals of both larval and adult Odonata a the Embrun lagoons.

either mature larvae or adults, or both depending on the time.

\section{Acknowledgments}

Craig Cullen, superintendent of public utilities for the township of Russell, assisted by providing extensive information on the lagoon systems at Embrun.

\section{Literature Cited}

Catling, P. M. 2004. A preliminary study of dragonflies at eastern Ontario sewage lagoons in relation to water quality. Pages 28 - 32 in Ontario Odonata, volume 4. Edited by P. M. Catling, C. D. Jones, and P. Pratt. Toronto Entomologists' Association, Toronto, Ontario, Canada.

Corbet, P. S. 1999. Dragonflies, behaviour and ecology of Odonata. Cornell University Press, Ithaca, New York. 829 pages.
Lefort, F., and P. M. Catling. 1998. A survey of damselfly adults at urban and non-urban streams at Ottawa, Ontario. Argia - the news journal of the dragonfly society of the Americas 10(4): 17-19.

Manoharan, R. 1985. Sewage lagoons in cold climates. Environmental Protection Service (Environment Canada) EPS4/NR/1. 89 pages.

Takamura, K., S. Hatakeyama, and H. Shiraishi. 1991. Odonate larvae as an indicator of pesticide contamination. Applied Entomology and Zoology 26: 321-326.

Walker, E. M. 1953. The Odonata of Canada and Alaska, volume 1, part 1: General. part 2: The Zygoptera - Damselflies. University of Toronto Press. 292 pages.

Watson, J. A. L., A. H. Arthington, and D. L. Conrick. 1982. Effect of sewage effluent on dragonflies (Odonata) of Bulimba Creek, Brisbane. Australian Journal of Freshwater Research 33: 517-528.

Received 30 April 2003

Accepted 26 April 2005 